\title{
Do Histopathological Findings of Kidney Biopsies Performed in Patients with Acute Kidney Injury Differ with Age?
}

\section{Akut Böbrek Hasarı Nedeniyle Yapılan Böbrek Biyopsilerinin Histopatolojik Bulguları Yaşla Değişir Mi?}

\author{
(D) Arzu Özdemir ${ }^{1}$, (1) Fatma Sibel Koçak Yücel' ${ }^{1}$, (1) Kamile Gülçin Eken², (D) Mürvet Yılmaz¹ \\ ${ }^{1}$ University of Health Sciences Turkey, Bakırköy Dr. Sadi Konuk Training and Research Hospital, Clinic of Nephrology, İstanbul, Turkey \\ ${ }^{2}$ University of Health Sciences Turkey, Şişli Hamidiye Etfal Training and Research Hospital, Clinic of of Pathology, İstanbul, Turkey
}

\begin{abstract}
Objective: Acute kidney injury (AKI) occurs in various conditions with different clinical presentations. Kidney biopsy (KB) is recommended when pre-renal and post-renal causes have been excluded, and the cause of AKI is unclear. We aimed to determine the histopathological features in patients with $\mathrm{AKI}$ and compare the frequency of the underlying causes in patients with different age groups.

Methods: This retrospective study was performed on all patients who underwent KB for AKI at our institution between January 2006 and April 2021. Demographic, clinical, and laboratory data and histopathological results were retrieved from the patients' files. Patients aged 60 years and older were regarded as elderly. The distribution of renal diseases was compared between the age groups.

Results: Overall, 767 kidney biopsies were performed at our institution for 15 years. Of these, 171 (22.2\%) had unexplained AKI, of whom $35 \%$ were elderly. Males were predominated in both groups. The most common diagnosis was glomerular diseases (71.9\%), followed by tubulointerstitial diseases (21.7\%) and vascular lesions (5.3\%). Immunoglobulin A nephropathy was the most frequent diagnosis in adults, whereas pauci-immune glomerulonephritis was the most frequent cause of $\mathrm{AKI}$ in the elderly.

Conclusion: Our data documents the different patterns of biopsy-confirmed causes of AKI according to the age groups and points the value of biopsy since most of the pathologic diagnoses are entities that are both difficult to diagnose without biopsy and are treatable.
\end{abstract}

Keywords: Acute kidney injury, histopathology, kidney biopsy

\section{öz}

Amaç: Akut böbrek hasarı $(A B H)$, farklı klinik bulgular ve farklı nedenler ile ortaya çıkabilir. $A B H^{\prime} y e$ yol açabilecek prerenal ve postrenal nedenler dışlandığında ve $\mathrm{ABH}$ 'nin nedeni saptanamadığında böbrek biyopsisi (BB) önerilir. Bu çalışmada, $\mathrm{ABH}$ ile başvuran hastalarda histopatolojik özelliklerin belirlenmesi ve farklı yaş gruplarındaki hastalarda altta yatan nedenlerin sıklığının karşılaştıııması amaçlandı.

Gereç ve Yöntem: Ocak 2006 ve Nisan 2021 tarihleri arasında ABH nedeniyle BB yaptığımız tüm hastalar geriye dönük olarak tarandı. Demografik, klinik ve laboratuvar verileri ile histopatolojik sonuçlar hasta dosyalarından kaydedildi. Altmış yaş ve üzeri hastalar yaşlı olarak kabul edildi. Böbrek hastalıklarının dağılımı yaş grupları arasında karşılaştırıldı.

Bulgular: On beş yılda yapılan 767 BB değerlendirildi. Yüz yetmiş birinde $(\% 22,2)$ açıklanamayan ABH vardı ve bunların \%35'i yaşlıydı. Her iki grupta da erkekler baskındı. En sık tanı glomerüler hastalıklar $(\% 71,9)$ iken, bunu tubulointerstisyel hastalıklar $(\% 21,7)$ ve vasküler lezyonlar $(\% 5,3)$ izledi. Erişkinlerde en sık karşılaşılan patolojik tanı immünoglobulin A nefropatisi iken yaşlılarda pauci-immün glomerulonefrit idi.

Sonuç: Verilerimiz; ABH'de BB sonuçlarının yaşa göre değiştiğini ve BB tanı ve tedavinin yönlendirilmesindeki değerini göstermektedir.

Anahtar Kelimeler: Akut böbrek hasarı, histopatoloji, böbrek biyopsisi

Address for Correspondence: Arzu Özdemir, University of Health Sciences Turkey, Bakırköy Dr. Sadi Konuk Training and Research Hospital, Clinic of Nephrology, İstanbul, Turkey

Phone: +90 5326957962 E-mail: arzukayalar@yahoo.com ORCID ID: orcid.org/0000-0001-7651-7282

Cite as: Özdemir A, Koçak Yücel FS, Eken KG, Yllmaz M. Do Histopathological Findings of Kidney Biopsies Performed in Patients with Acute

Kidney Injury Differ with Age? Med J Bakirkoy 2021;17:243-247

Received: 15.08.2021

Accepted: 15.09.2021 


\section{INTRODUCTION}

Acute kidney injury (AKI) is a heterogeneous disorder, manifested by an increase in serum creatinine level with or without reduced urine output for hours to days $(1,2)$. Injury ranges from mild to severe kidney failure, sometimes requiring dialysis. Moreover, AKI is associated with an increased risk of mortality and development of chronic kidney disease (3). The diagnostic evaluation can be used to classify AKI as pre-renal AKI, which results from inadequate perfusion of the kidneys, and post-renal AKI, which results from obstruction to the flow of urine and renal $\mathrm{AKI}$, which can be due to injury or dysfunction of the renal glomeruli, tubules, interstitium, or blood vessels. The majority of AKI cases can be diagnosed by clinical history, physical examination, and investigations of urine, blood, and radiology tests. Kidney biopsy (KB) is a crucial diagnostic tool when pre-renal and post-renal causes have been excluded and the intrinsic cause of AKI is unclear (4). Further, KB is critical for correct treatment and predicting prognosis. Patients undergoing KB for evaluation of AKI had a higher risk for complications due to lower pre-biopsy hemoglobin and higher baseline serum creatinine (5). Therefore, clinicians must consider diagnostic uncertainty and potential therapeutic relevance when deciding to perform a diagnostic KB in patients with $\mathrm{AKI}$ and take all precautions to prevent complications. This study aimed to determine the histopathological features in patients presenting with $\mathrm{AKI}$ and to compare the frequency of the different causes in patients with different age groups.

\section{METHODS}

Our study was retrospective, including all patients who underwent native KB for AKI. All native kidney biopsies performed at University of Health Sciences Turkey Bakırköy Dr. Sadi Konuk Training and Research Hospital between January 2006 and April 2021 were screened. Indications for kidney biopsies are as follows:

1. AKI: Abrupt decrease in renal function, with or without oligoanuria or rapidly progressive renal failure, including worsening of chronic kidney disease

2. Nephrotic syndrome: Proteinuria $>3.5 \mathrm{~g} / 24 \mathrm{~h}$, with hypoalbuminemia (serum albumin $<3.5 \mathrm{~g} / \mathrm{L}$ ) and edema

3. Nephritic syndrome: Proteinuria (1.5-3.5 g/24 h), hematuria with or without high blood pressure, and edema

4. Urinary abnormalities: Proteinuria $<1.5 \mathrm{~g} /$ day or hematuria, without impaired kidney function

The renal specimens were collected by biopsy needle guidance technique under ultrasonography. The same pathologist examined the KB specimens and processed them for standard analysis, including light microscopy with hematoxylin-eosin, periodic acid-Schiff, Masson's trichrome, and periodic acid-methenamine silver staining and immunofluorescence. Patients were eligible if aged $\geq 16$ years and submitted to KB for AKI. The exclusion criteria were incomplete records, inadequate biopsies $(<8$ glomeruli), and transplant kidney biopsies.

For all cases in which the indication for biopsy was AKI, we reviewed the patient's files, including the renal biopsy report. We recorded the following information: Age, sex, comorbidities, laboratory findings at the time of biopsy (serum creatinine, serum albumin, urine microscopy, 24hour urine protein or spot urine protein/creatinine ratio, ANCA serological results), and histopathological diagnosis. Renal diseases were classified into three major categories: glomerular diseases, tubulointerstitial nephropathies, and vascular lesions. Patients aged 60 years and older were regarded as elderly.

\section{Statistical Analysis}

The 2007 NCSS (Number Cruncher Statistical System; Kaysville, Utah, USA) program was used for statistical analysis. Descriptive statistical methods (mean, standard deviation, median, frequency, ratio, minimum, maximum) were used for study data evaluation. The suitability of quantitative data to normal distribution was tested by Kolmogorov-Smirnov, Shapiro-Wilk test, and graphical evaluations. Student's t-test was used to determine the significance of differences between normally distributed variables and Mann-Whitney $U$ test for non-normally distributed variables. Pearson chisquare test, Fisher-Freeman-Halton Exact test, and Fisher's Exact test were used to compare qualitative data, where appropriate. $P<0.05$ was considered statistically significant.

\section{RESULTS}

Of the 767 kidney biopsies performed at our institution for 15 years, 171 (22.2\%) were conducted on patients with unexplained AKI (Table 1). The frequency of biopsyconfirmed AKI in adult patients was 18.5\%, increasing to $36 \%$ in the elderly $(p=0.001)$. As shown in Table 2 , no statistically significant differences was observed in sex, serum creatinine, serum albumin, and proteinuria level between the age groups ( $p>0.05)$.

Table 3 lists the histological lesions encountered in the patients with $\mathrm{AKI}$, subclassified according to age and primary site of involvement within the kidney. Glomerular disease was the most common type of disease observed in both groups [81 (72.9\%) in the adults vs 42 (70\%) in the elderly group]. The distribution of glomerular lesions 
differed between the age groups. Immunoglobulin A nephropathy was the most common cause (36\%) in adults, whereas pauci-immune glomerulonephritis (GN) was the most frequent pathology (33.3\%) in the elderly $(p=0.001$ and $p=0.001$, respectively). Fifty-six (32.7\%) patients presented with rapidly progressive GN: 18 had crescentic immunoglobulin A nephropathy, 32 had pauci-immune GN, 4 had anti-glomerular basement membrane disease, 1 had lupus nephritis class IV, and 1 had shunt nephritis. In detail, immunosuppressive treatment was applied to all of these patients, and seven patients with pauci-immune GN who had hemoptysis and/or radiologic evidence of pulmonary involvement were treated with plasmapheresis.

Table 1. Clinical presentations at the time of biopsy according to age

\begin{tabular}{|c|c|c|c|c|}
\hline & $\begin{array}{c}\text { Total } \\
n=767 \\
(100 \%)\end{array}$ & $\begin{array}{l}\text { Adult }(<60 \\
\text { years) } \\
\mathrm{n}=603 \\
(78.6 \%)\end{array}$ & $\begin{array}{l}\text { Elderly } \\
\text { ( } \geq 60 \text { years) } \\
n=164 \\
(21.4 \%)\end{array}$ & $p$ \\
\hline $\begin{array}{l}\text { Acute kidney } \\
\text { injury }(n, \%)\end{array}$ & $\begin{array}{c}171 \\
(22.2)\end{array}$ & 114 (18.9) & $57(34.7)$ & \multirow{4}{*}{$\mathrm{d} 0.001^{\text {** }}$} \\
\hline $\begin{array}{l}\text { Nephrotic } \\
\text { syndrome } \\
(n, \%)\end{array}$ & $\begin{array}{l}309 \\
(40.2)\end{array}$ & $234(38.8)$ & 75 (45.7) & \\
\hline $\begin{array}{l}\text { Nephritic } \\
\text { syndrome } \\
(n, \%)\end{array}$ & $\begin{array}{l}113 \\
(14.7)\end{array}$ & $97(16.1)$ & $16(9.7)$ & \\
\hline $\begin{array}{l}\text { Abnormal } \\
\text { urine analysis } \\
(n, \%)\end{array}$ & $\begin{array}{l}174 \\
(22.6)\end{array}$ & $158(26.2)$ & $16(9.7)$ & \\
\hline
\end{tabular}

Tubulointerstitial disease (TID) was noted approximately in $20 \%$ of the cases in both age groups. The most commonTID was tubulointerstitial nephritis (TIN) in two groups.

Vascular disease was the least common cause of AKI (5.3\%). Noticeably, the most common vascular disease was hypertensive nephrosclerosis. All patients diagnosed with hemolytic uremic syndrome (HUS) were adults, and the frequency of renal cortical necrosis (RCN) was similar in the age groups.

About $49.1 \%$ of the patients required hemodialysis. Indications of hemodialysis included uremia, oligoanuria, metabolic acidosis, and hyperkalemia. Although we had incomplete data to quantify complications of $K B$, no major complications such as death and nephrectomy were reported.

\section{DISCUSSION}

Several registries have described clinicopathological spectrums of kidney biopsies in adults; however, a limited number of these studies analyzed the primary clinical syndromes that indicate KB in detail. This observational study describes the histopathological profiles of the patients undergoing a KB for $\mathrm{AKI}$ and highlights the difference in age prevalence of the different causes.

The incidence of $A K I$ as a clinical syndrome in the study of kidney biopsies ranges from $10 \%$ to $25 \%$ (6-12). Our data collected over 15 years showed that AKI constitutes $22.2 \%$ of all KB; however, this percentage was lower in adult patients than in the elderly. It is crucial to say that structural and functional changes occurring with age make

Table 2. Demographic and biochemical characteristics of the patients with AKI at presentation according to age

\begin{tabular}{|c|c|c|c|c|}
\hline & $\begin{array}{l}\text { Total } \\
n=171(100 \%)\end{array}$ & $\begin{array}{l}\text { Adults } \\
\mathrm{n}=111(64.9 \%)\end{array}$ & $\begin{array}{l}\text { Elderly } \\
n=60 \text { (35\%) }\end{array}$ & $p$ \\
\hline Age (years) (mean $\pm \mathrm{SD})$ & $49.39 \pm 16.22$ & $40.41 \pm 11.61$ & $67.37 \pm 5.85$ & - \\
\hline Male & $47.35 \pm 16.75$ & $38.60 \pm 11.27$ & $67.77 \pm 6.27$ & \\
\hline Female & $52.28 \pm 15.00$ & $43.30 \pm 11.69(16-59)$ & $66.93 \pm 5.42(60-81)$ & \\
\hline $\operatorname{Sex}(n, \%)$ & - & - & - & b0.272 \\
\hline Male & $100(58.4)$ & $67(67)$ & $33(33)$ & \\
\hline Female & $71(41.5)$ & $44(62)$ & $27(38)$ & \\
\hline Laboratory on admission (mean \pm SD) & - & - & - & - \\
\hline Creatinine (mg/dL) & $4.86 \pm 2.76$ & $5.08 \pm 2.82$ & $4.42 \pm 2.62$ & ${ }^{\circ} 0.107$ \\
\hline Total protein $(\mathrm{g} / \mathrm{dL})$ & $6.16 \pm 0.90$ & $6.20 \pm 1.01$ & $6.07 \pm 0.73$ & ${ }^{\mathrm{a}} 0.501$ \\
\hline Albumin (g/dL) & $3.27 \pm 0.69$ & $3.31 \pm 0.72$ & $3.20 \pm 0.59$ & ${ }^{\mathrm{a}} 0.430$ \\
\hline Proteinuria $(\mathrm{mg} / \mathrm{g})$ & $3148 \pm 2847$ & $3274.35 \pm 2906.61$ & $2897.86 \pm 2734.79$ & ${ }^{c} 0.268$ \\
\hline
\end{tabular}




\begin{tabular}{|c|c|c|c|c|}
\hline & $\begin{array}{l}\text { Total } \\
n=171(100 \%)\end{array}$ & $\begin{array}{l}\text { Adults } \\
\mathrm{n}=111(64.9 \%)\end{array}$ & $\begin{array}{l}\text { Elderly } \\
\mathrm{n}=60 \text { (35.1\%) }\end{array}$ & $\mathrm{p}$ \\
\hline Glomerular diseases & $123(71.9)$ & $81(72.9)$ & $42(70.0)$ & 0.680 \\
\hline Anti-GBM nephritis & $4(2.3)$ & $3(2.7)$ & $1(1.6)$ & $\mathrm{d} 1.000$ \\
\hline Amyloidosis (AA/AL) & $6 / 3(5.2)$ & $4 / 1(4.5)$ & $2 / 2(6.6)$ & ${ }^{d} 0.697$ \\
\hline Chronic glomerulonephritis & $4(2.3)$ & $3(2.7)$ & $1(1.6)$ & ${ }^{d} 0.553$ \\
\hline Diabetic nephropathy & $6(3.6)$ & $1(0.9)$ & $5(8.3)$ & d 0.186 \\
\hline Focal segmental GS & $8(4.6)$ & $7(6.3)$ & $1(1.6)$ & ${ }^{d} 0.263$ \\
\hline IgA nephropathy & 49 (28.6) & $40(36)$ & $9(15)$ & $0.001 *$ \\
\hline Lupus nephritis & $3(1.7)$ & $3(2.7)$ & 0 & d 0.553 \\
\hline Membranoproliferative GN & $7(4.1)$ & $6(5.4)$ & $1(1.6)$ & ${ }^{d} 0.424$ \\
\hline Pauci-immune crescentic GN & $32(18.7)$ & $12(10.8)$ & $20(33.3)$ & $0.001 * *$ \\
\hline Shunt nephritis. & $1(0.5)$ & $1(0.9)$ & 0 & $\mathrm{~d}_{1} .000$ \\
\hline Tubulointerstitial diseases & $37(21.7)$ & $23(20.7)$ & $14(23.3)$ & 0.701 \\
\hline Tubulointerstitial nephritis & $24(14)$ & $16(14.4)$ & $8(13.3)$ & 1.000 \\
\hline Acute tubular necrosis & $13(7.6)$ & $7(6.3)$ & $6(10)$ & $\mathrm{d} 0.383$ \\
\hline Vascular diseases & $9(5.3)$ & $6(5.4)$ & $3(5)$ & $\mathrm{d} 1.000$ \\
\hline Hemolytic uremic nephropathy & $3(1.7)$ & $3(2.7)$ & 0 & d 0.553 \\
\hline Hypertensive nephrosclerosis & $4(2.3)$ & $2(1.8)$ & $2(3.3)$ & ${ }^{d} 0.613$ \\
\hline Acute cortical necrosis & $2(1.1)$ & $1(0.9)$ & $1(1.6)$ & $\mathrm{d}_{1} \mathbf{0 0 0}$ \\
\hline Unclassified & $2(1.1)$ & $1(0.9)$ & $1(1.6)$ & $\mathrm{d} 1.000$ \\
\hline Oxalate nephropathy & $1(0.5)$ & $1(0.9)$ & 0 & $\mathrm{~d}_{1} \mathbf{0 0 0}$ \\
\hline Phosphate nephropathy & $1(0.5)$ & 0 & $1(1.6)$ & d1.000 \\
\hline
\end{tabular}

the elderly more vulnerable to AKI, and once it happened, renal function did not recover fast after the induction of treatment in the older age group.

In both age groups, glomerular diseases accounted for $70 \%$ of all diagnoses, similar to the previous studies, in which $\mathrm{GN}$ was the primary finding in $\geq 50 \%$ of cases undergoing $\operatorname{KB}$ for $\operatorname{AKI}(8,11,12)$. The most common diagnosis was immunoglobulin A nephropathy in adults, which accounted for nearly one-third of the cases, and it causes AKI probably by hematuria and/or crescentic proliferation. Consistent with the previous report (8), the most common glomerular disease in elderly patients was pauci-immune $G N$ in our cases. In the current study, $32.7 \%$ of the patients showed crescentic proliferation, and approximately $57.1 \%$ had pauci-immune GN. Regarding the higher prevalence of crescentic GN among AKI patients, early diagnosis is necessary to prevent irreversible kidney injury by initiating immunosuppressive treatment and plasmapheresis when appropriate.

TID includes TIN and ATN, both of which cause a rapid decline in kidney function. TIN is characterized by interstitial inflammatory infiltrates, edema, and tubulitis in histopathological examination and is usually caused by drugs, infection, and systemic and autoimmune disease and may be idiopathic in origin. It accounts for $2 \%$ of all native kidney biopsies and $15-27 \%$ of adult cases undergoing KB for unexplained $\mathrm{AKI}(8,13,14)$. TIN was the most common type of TID observed in our cohort and accounted for $14 \%$ of all biopsy cases. Clinical suspicion, particular attention to extrarenal manifestations, and review of potential risk factors are usually enough for accurate diagnosis of TIN. However, KB should be performed in cases with severe renal dysfunction, lack of an identifiable offending agent, and lack of renal recovery before initiation of immunosuppressive treatment. 
ATN is a common etiology of AKI in hospitalized patients and is diagnosed by exclusion of pre-renal and postrenal causes of $A K I$, examination of urinary sediment, and analysis of urine measures such as fractional excretion of sodium. ATN prevalence in our cohort is low because most cases were diagnosed based on clinical data, and KB was performed only in patients with prolonged or atypical AKI. In fact, histopathological findings of ATN are only diagnostic and do not alter therapy, and its role in predicting renal outcome is unknown.

Vascular diseases are the least common cause of AKI in the present study. Hypertensive nephrosclerosis was present in $2.3 \%$ of our cases, which was similar to the findings of a report from Japan (1.3\%) (15). HUS characterized by non-immune microangiopathic hemolytic anemia, thrombocytopenia, and AKI was detected in three patients and all were treated with eculizumab. RCN secondary to ischemic necrosis of the renal cortex is a rare disease, accounting for only $2 \%$ of all cases of AKI in Western countries and 3.8\%-7.1\% in patients dialyzed for AKI in developing countries $(16,17)$. In line with the literature, we reported RCN in $1.1 \%$ of the cases, and none was associated with obstetrical complications.

\section{Study Limitations}

This study had a few limitations. Our study did not include follow-up or outcome data, and these entities must be studied in future studies.

\section{CONCLUSION}

The present study provides information about renal histopathology in patients with $A K I$ and reveals the significance of $K B$ for accurate diagnosis of underlying diseases as most of the histopathological diagnoses are entities that are both difficult to recognize without biopsy and are treatable.

\section{ETHICS}

Ethics Committee Approval: The study were approved by the University of Health Sciences Turkey, Bakırköy Dr. Sadi Konuk Training and Research Hospital of Local Ethics Committee (approval no: 214/2021).

Informed Consent: Retrospective study.

\section{Authorship Contributions}

Surgical and Medical Practices: A.Ö., F.S.K.Y., K.G.E., M.Y., Concept: A.Ö., M.Y., Design: A.Ö., F.S.K.Y., M.Y., Data Collection or Processing: A.Ö., F.S.K.Y., K.G.E., Analysis or Interpretation: A.Ö., F.S.K.Y., K.G.E., Literature Search: A.Ö., Writing: A.Ö.
Conflict of Interest: No conflict of interest was declared by the authors.

Financial Disclosure: The authors declared that this study received no financial support.

\section{REFERENCES}

1. Mehta RL, Kellum JA, Shah SV, Molitoris BA, Ronco C, Warnock DG, et al. Acute Kidney Injury Network: report of an initiative to improve outcomes in acute kidney injury. Crit Care 2007;11:R31.

2. Khwaja A. KDIGO clinical practice guidelines for acute kidney injury. Nephron Clin Pract 2012;120:c179-84.

3. Forni LG, Darmon M, Ostermann M, Oudemans-van Straaten HM, Pettilä V, Prowle JR, et al. Renal recovery after acute kidney injury. Intensive Care Med 2017;43:855-66.

4. Kellum JA, Lameire N, Aspelin P, BarsoumRS, Burdmann EA, GoldsteinSL, et al. Kidney disease: improving global outcomes (KDIGO) acute kidney injury work group. KDIGO clinical practice guideline for acute kidney injury. Kidney Int Supp 2012;2:1-138.

5. Korbet SM, Gashti CN, Evans JK, Whittier WL. Risk of percutaneous renal biopsy of native kidneys in the evaluation of acute kidney injury. Clin Kidney J 2018;11:610-5.

6. Nash K, Hafeez A, Hou S. Hospital-acquired renal insufficiency. Am $\mathrm{J}$ Kidney Dis 2002;39:930-6.

7. Tøndel C, Vikse BE, Bostad L, Svarstad E. Safety and complications of percutaneous kidney biopsies in 715 children and 8573 adults in Norway 1988-2010. Clin J Am Soc Nephrol 2012;7:1591-7.

8. Haas M, Spargo BH, Wit EJ, Meehan SM. Etiologies and outcome of acute renal insufficiency in older adults: a renal biopsy study of 259 cases. Am J Kidney Dis 2000;35:433-47.

9. Stratta P, Canavese C, Marengo M, Mesiano P, Besso L, Quaglia M, et al. Risk management of renal biopsy: 1387 cases over 30 years in a single centre. Eur J Clin Invest 2007;37:954-63.

10. Uezono S, Hara S, Sato Y, Komatsu H, Ikeda N, Shimao Y, et al. Renal biopsy in elderly patients: a clinicopathological analysis. Ren Fail 2006;28:549-55.

11. López-Gómez JM, Rivera F; Spanish Registry of Glomerulonephritis. Renal biopsy findings in acute renal failure in the cohort of patients in the Spanish Registry of Glomerulonephritis. Clin J Am Soc Nephrol 2008;3:674-81.

12. Schena FP. Survey of the Italian Registry of Renal Biopsies. Frequency of the renal diseases for 7 consecutive years. The Italian Group of Renal Immunopathology. Nephrol Dial Transplant 1997;12:418-26.

13. Clarkson MR, Giblin L, O'Connell FP, O'Kelly P, Walshe JJ, Conlon $P$, et al. Acute interstitial nephritis: clinical features and response to corticosteroid therapy. Nephrol Dial Transplant 2004;19:2778-83.

14. Baker RJ, Pusey CD. The changing profile of acute tubulointerstitial nephritis. Nephrol Dial Transplant 2004;19:8-11.

15. Sugiyama H, Yokoyama $H$, Sato $H$, Saito T, Kohda $Y$, Nishi $S$, et al. Japan Renal Biopsy Registry and Japan Kidney Disease Registry: Committee Report for 2009 and 2010. Clin Exp Nephrol 2013;17:155-73.

16. Prakash J, Singh VP. Changing picture of renal cortical necrosis in acute kidney injury in developing country. World J Nephrol 2015:4:480-6.

17. Prakash J, Vohra R, Wani IA, Murthy AS, Srivastva PK, Tripathi K, et al. Decreasing incidence of renal cortical necrosis in patients with acute renal failure in developing countries: a single-centre experience of 22 years from Eastern India. Nephrol Dial Transplant 2007;22:1213-7. 